\title{
Relative dating of moraines from the arid part of Altai: apply- ing of rock weathering and colonization by biota data within the framework of the method
}

\author{
Dmitrii A. Ganyushkin ${ }^{*}$, Sofia N. Lessovaia ${ }^{2}$, Dmitrii Y. Vlasov³, Gennady P. Kopitsa ${ }^{4,5}$, László Almásy ${ }^{6}$, Kirill V. \\ Chistyakov $^{7}$, Elena G. Panova ${ }^{8}$, Ekaterina Derkach ${ }^{9}$, Anastasiya Alekseeva ${ }^{10}$ \\ 1 St. Petersburg State University, Institute of Earth Sciences, Universitetskaya nab., d. 7/9, St. Petersburg, \\ 199034, Russia, d.ganyushkin@spbu.ru \\ 2 St. Petersburg State University, Institute of Earth Sciences, Universitetskaya nab., d. 7/9, St. Petersburg, \\ 199034, Russia, s.lesovaya@spbu.ru \\ 3 St. Petersburg State University Biological Faculty, Universitetskaya nab., d. 7/9, St. Petersburg, 199034, Rus- \\ sia 2 dmitry.vlasov@mail.ru \\ 4 B.P. Konstantinov Petersburg Nuclear Physics Institute NRC KI, Orlova roshcha, d. 1, Gatchina, 188300, \\ Russia \\ 5 I.V. Grebenshchikov Institute of Silicate Chemistry RAS, nab. Adm. Makarova, d. 2, St. Petersburg, 199155, \\ Russia Petersburg Nuclear Physics Institute NRC KI, Orlova roshcha, d. 1, Gatchina, 188300, Russia, ko- \\ pitsa gp@pnpi.nrcki.ru \\ 6 Institute for Solid State Physics and Optics, Wigner Research Centre for Physics, Hungarian Academy of \\ Sciences, POB 49 Budapest 1525, Hungary, almasy@mail.kfki.hu \\ 7 St. Petersburg State University, Institute of Earth Sciences, Universitetskaya nab., d. 7/9, St. Petersburg, \\ 199034, Russia, k.chistyakov@spbu.ru \\ 8 St. Petersburg State University, Institute of Earth Sciences, Universitetskaya nab., d. 7/9, St. Petersburg, \\ 199034, Russia, elena-geo@list.ru \\ 9 St. Petersburg State University, Institute of Earth Sciences, Universitetskaya nab., d. 7/9, St. Petersburg, \\ 199034, Russia, st040761@student.spbu.ru, katya.d96@bk.ru \\ 10 St. Petersburg State University, Institute of Earth Sciences, Universitetskaya nab., d. 7/9, St. Petersburg, \\ 199034, Russia, asja612@yandex.ru \\ * Correspondence: d.ganyushkin@spbu.ru or Ganushkinspbgu@mail.ru; Tel.: +7-921-3314-598
}

\begin{abstract}
For the Altai mountainous region, especially the arid south-eastern part, the history of glacier fluctuations in Pleistocene and Holocene is still poorly known. The key plots were located in the Kargy valley (2288-2387 $\mathrm{m}$ a. s. 1.) that is not currently affected by glaciations. The relative dating method was applied to define Pleistocene moraine chronology and configuration in the Kargy valley. Taking into account that relative dating methods are primarily based on weathering patterns, the mineralogy, porosity, and specificity of biological colonization as an agent of weathering were obtained for the moraine samples. Three moraine groups of different age (presumably MIS 6, MIS 4 , and MIS 2) were identifies based on detailed investigation of morphological features. The moraine age was indirectly confirmed by the mesostructure of the moraine samples represented by finegrained shale: the older sample is characterized by a more developed fractal surface than the younger one. The growth of biota (crustose lichen and micromycetes) leads to initial biomass accumulation and subsequent rock disintegration. The accumulation of autochthonous fine earth on the rock surface was considered the initial stage of fine earth formation affected by biota.
\end{abstract}

Keywords: biota colonization; weathering; rock porosity; Pleistocene moraines; moraine relativedating.

\section{Introduction}

Studying of Quaternary history of mountainous regions of the world nowadays is impossible without different numeric techniques for age determination of sediments [1], 
however their precision and accuracy are different and specific of the region studied plays a great role in their application. For the Altai mountainous region, the history of glacier fluctuations in Pleistocene and Holocene is still poorly known mainly because of the problems of bringing together the results obtained by different methods, which cause discussions [2-5].

This is especially true for the arid south-eastern Altai mountainous, where the opportunities of absolute dating of glacial deposits by isotopic methods are limited. 14Cdating is the most reliable method, but it requires buried organic material which is rare in the glacial valleys of the region. Moreover, the age of moraines can easily be beyond the time limits for this method. 10Be-dating, which is the most widely used among the surface exposure dating methods requires the presence of a sufficient amount of quartz in the boulders. Usage of luminescent methods also has limitations based on which the suitable conditions are easily met for aeolian deposits formed by the wind. But there is always possibility that the sandy interlayers in the strata of glacial deposits were deposited not on the day surface, but under the glacier. As a result, dating will give false ideas about the age of the moraines.

Hereby, methods of relative dating are becoming important in determining the age of glacial deposits, in particular quantitative relative dating methods where the weathering of boulders and soils and degradation of the moraine landform are used as a measure of relative moraine age. Quantitative approach to relative dating has been used at least from mid-XX century. Characteristics of fresh and weathered granitic clasts were given by [6], besides several researches used the ratio of fresh-to-weathered granitic stones for this purpose [7-10].

However, granite weathering ratio in many cases gives no result because of rock differences in mineralogy and as a consequence its sensitivity to weathering [11]. Whereas, it was revealed that the abundance of surface boulders decreased with age, slope angle, loess mantle thickness, and soil development (the depth to which the underlying gravel has been oxidized) of terraces correlated with the moraines can be used as indicators for relative dating [11]. Later, several parameters such as the relative number in shearstrained boulders, the degree of embedment into finely-grained material were included for relative dating of moraines in the south-eastern Altai [12].

In the 1980-s the clast-sound velocity (CSV) technique $[13,14]$ was developed as an independent relative dating method with which to compare the results of the morphometric analysis. The sound or P-wave velocity (VP) is measured in boulders on moraine crests. VP decreases as boulders become more pervasively riddled with microcracks during weathering. The older are the moraines and the longer are the boulders weathered the denser is the microcrack network, and the lower average VP and vice versa.

Another approach of measuring the grade of weathering of rocks is Schmidt-hammer method that gives an opportunity to measure the rebound value $(R)$ and a relative measure of the surface hardness providing information on the time of surface exposure and the degree of weathering [15]. This method has been successfully applied for relative age dating of moraines [16-18]. A strong coefficient of determination was found between Schmidt hammer rebound number with P-wave velocity of the tested different rocks [19]. Recently the pebble count procedure [20] was presented as an additional relative dating technique for establishing relative age relationships among moraines of the same locale [21]. The thickness of the weathering rind, a reddish outer crust-layer around individual rock components, is also used now as a possible age marker for moraines and rock glaciers. The use of weathering rates from rinds on several rock types for relative to absolute age dating of Quaternary deposits has been discussed [22-26].

At the moment there is no experience of relative dating of moraines of arid part of Altai except [12,27] and our recent article, dedicated to the paleoglaciation of the MongunTaiga massif [28]. The present research was aimed to apply the relative dating method for defining the Pleistocene moraine chronology and configuration based on the Kargy river valley located in arid Altai. Taking into account that relative dating methods are primarily 
based on weathering patterns, the mineralogy, porosity, and specificity of biological colonization as an agent of weathering were obtained for the moraine samples.

\section{Materials}

The key plots, which were selected to define the chronology and configuration of Pleistocene moraines, were located in Kargy valley in the upper reaches of the river. This area belongs to the north-eastern part of the Dzhulukul depression, which is situated above the present-day tree line level. The elevations of the key plots are $2288-2387 \mathrm{~m}$ a.s.l. The Kargy river flows from the southern slope of the Shapshalsky ridge in the south-eastern part of the Altai mountains (Russia) into lake Ureg-Nur (Mongolia) (Figure 1).

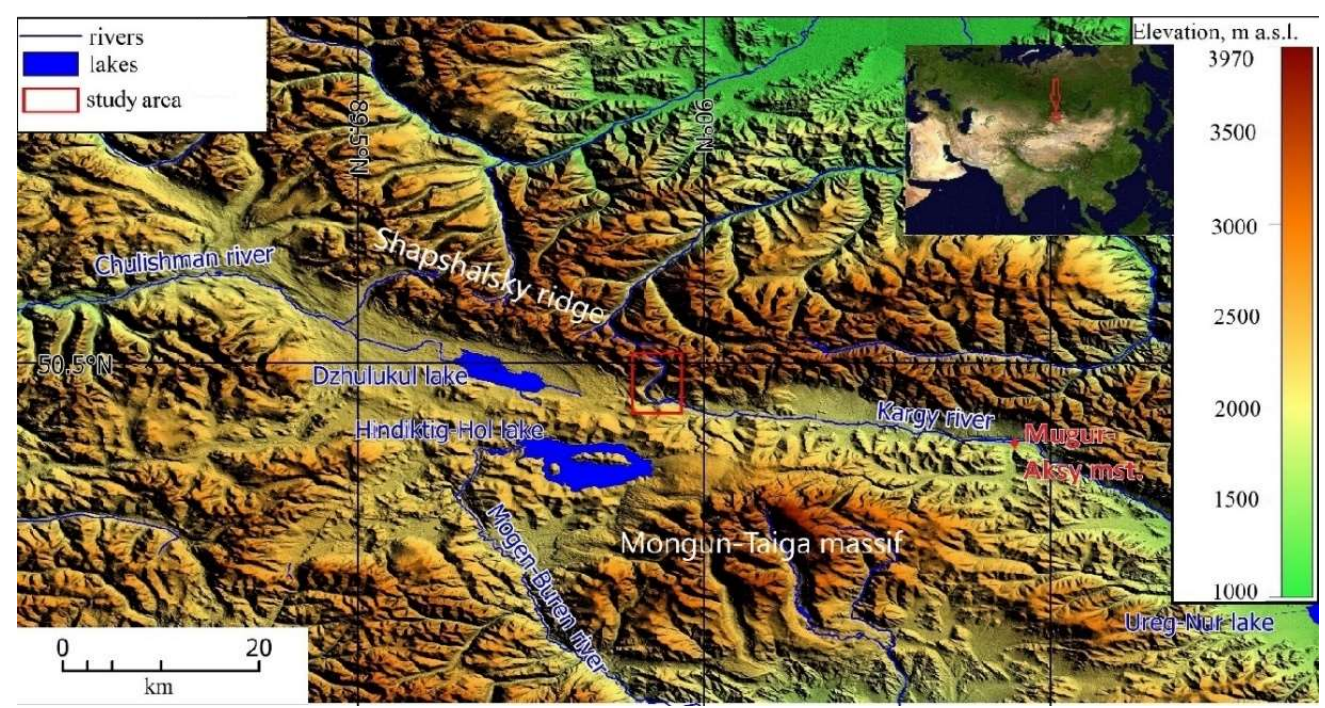

Figure 1. Location of the study area.

The valley, which is not currently affected by glaciations, is characterized by a sharply continental climate with a low amount of precipitation that is less than potential evapotranspiration; a large temperature range; and a negative average annual temperature. The closest meteorological station Mugur-Aksy at elevation $1830 \mathrm{~m}$ a.s.l. is $38 \mathrm{~km}$ to the east from the study area. Based on the data of the station, the climate characteristics are: MAP (mean annual precipitation) $156 \mathrm{~mm}$ within $75 \%$ as water; MAT (mean annual temperature) $-2.6^{\circ} \mathrm{C}$. More than $80 \%$ of precipitation falls in summer due to the local cyclogenesis. In winter, the region is dominated by the Siberian anticyclone, as a result the snow thickness is low (average maximum is $7 \mathrm{~cm}$ ). The annual average month temperature variation is $34.3^{\circ} \mathrm{C}$ [29]. Taking into account the elevation difference of the study plots and the meteorological station, the regional altitude thermal gradient $\left(0.69^{\circ} \mathrm{C} / 100 \mathrm{~m}\right)$ and altitudinal precipitation gradient calculated for the adjacent Mongun-Taiga massif (7 $\mathrm{mm} / 100 \mathrm{~m})[29,30]$ can be used. Using the gradients, MAT varies from $-8.1^{\circ} \mathrm{C}$ to $-9.6^{\circ} \mathrm{C}$ and MAP from 179 to $193 \mathrm{~mm}$. The Mongun-Taiga massif is also a center of present glaciation. Past and present dynamical trends of the glaciers of the massif were recently revealed $[28,31]$. The moraine chronology and configuration have been obtained using relative-dating method, which was confirmed and correlated by a combination of absolute $\left({ }^{14} \mathrm{C}\right)$ and relative dating techniques [28]. That allows applying the relative dating method to define the moraine chronology in the Kargy valley.

Two profiles sampled for moraine relative-dating were laid along the sides of the Kargy river. Measurements were carried out at 10 polygons (4 polygons on the left side of the valley and 6 polygons on the right side of the valley) where about 280 boulders were described and analyzed (Figure 1). The choice of polygons for relative dating was dictated by the distinctness of the moraines, their preservation from the point of view of erosion 
processes, and the presence of stable areas on the ridges of the moraines. Taking into account that relative dating methods are primarily based on weathering patterns, the moraine samples from 3 polygons were obtained to study the mineralogy, porosity, and specificity of biological colonization as an agent of weathering.

\section{Methods}

\subsection{Geomorphology Study}

At the preliminary stage of the field work, the delineation of moraines in satellite imagery and morphological description of the moraines of the Kargy river valley was carried out.

\subsection{Moraine Relative-dating Method}

On a polygon (moraine) having an area of $100 \mathrm{~m}^{2}$, boulders with a diameter over 30 $\mathrm{cm}$ were counted and analyzed. Then features were delineated that involved the number of boulders having a diameter over $30 \mathrm{~cm}(\mathrm{~N})$, the presence of shear-strained boulders $(\mathrm{C}$, $\%$ ) and flat-topped boulders (F, \%), the degree of embedment into finely-grained material $(B, \%)$, lichen coverage $(\mathrm{L}, \%)$, rock surface hardness $(\mathrm{R})$ [28]. The rock surface hardness dimension was realized using an N-type Schmidt hammer [32,33]. It is a portable instrument originally developed to test concrete quality in a non-destructive way, which also can measure the rebound value of a boulder [16,32,33]. A spring-loaded bolt influencing on a rock surface yields a rebound (or R-value) that is proportional to the hardness (compressive strength) of the rock surface. All influences were performed with the hammer held vertically downwards and at right angles to the horizontal rock faces. According to geomorphology, more weathered surfaces are characterized by low R-values and less weathered surfaces correspondingly by high R-values [34]. Three measurements were registered for each boulder at the polygon and then the average value was counted.

\subsection{Mineralogy Composition of the Moraine Samples}

Petrography and mineralogy of rock fragments (moraines) were studied in thin sections by optical microscopy using a Leica DM LP microscope.

\subsection{Specific Surface Area of Moraine Samples and Pore Size Distribution}

The specific surface area (the total surface area of a material per unit of mass) and the pore size distribution in the moraine samples were determined by low-temperature nitrogen adsorption method using a QuantaChrome Nova 1200e analyzer (Quantachrome Instuments, Florida, USA). The samples were degassed in a drying chamber at $100^{\circ} \mathrm{C}$ during 19 hours; then the samples were analyzed by the multipoint Brunauer-Emmett-Teller (BET) method using 7 points. The pore size distribution was calculated by the BarretJoyner-Halenda (BJH) method using nitrogen desorption isotherm (NOVAWin ${ }^{\mathrm{TM}}$ - Windows ${ }^{\circledR}$ Based Software for Operation from PC). The method allows to investigate the pores with diameter $<100 \mathrm{~nm}$ [35].

\subsection{Mesostructure and Fractal Properties of Moraine Samples}

The mesostructure and fractal properties of the moraines were investigated by the small angle neutron scattering (SANS) method. The SANS experiment was performed at the "Yellow Submarine" instrument (BBR research reactor in Budapest Neutron Center, Hungary), which operates in near point geometry. Using of neutron wavelength $(\lambda=0.49$ $\mathrm{nm}, \Delta \lambda / \lambda=18 \%$ ) and two sample-to-detector distances $(1.6$ and $5.6 \mathrm{~m})$ provides the measurements in the momentum transfer range $(q)$ of $6.5 \cdot 10^{-2}<q<4 \mathrm{~nm}^{-1}$ (where: $q=4 \pi \lambda$ ${ }^{1} \sin (\theta / 2), \theta$ is the scattering angle), which correspond to analysis of the rock structure in the range $D \approx 2 \pi / q$ from 1 to $100 \mathrm{~nm}$. The scattered neutrons were detected by a twodimensional position-sensitive $\mathrm{BF}_{3}$ gas detector $(64 \times 64$ cells of $1 \mathrm{~cm} \times 1 \mathrm{~cm})$. 
The sample powders were placed in $1 \mathrm{~mm}$ thick quartz cells. Apparent density $\rho$ H of each sample was calculated as the weight of the powder divided by its volume. The raw data were corrected using the standard procedure [36], taking into account the scattering from the setup equipment and cell. The resulting 2D isotropic spectra were averaged azimuthally and their absolute values were determined by normalizing to the incoherent scattering cross section of water and apparent density $\rho$ H for each sample. Data pre-processing was obtained using the BerSANS software [37].

\subsection{Identification of Biota on the Rock Surface}

The initial analyze of the moraine samples, oxidized ring, and lichen distribution on the rock surface was carried out using a stereomicroscope Leica M 80. Visualization of lichen that has colonized the moraine samples was carried out in untreated samples using Color 3D Laser Microscope (KEYENCE VK-9700 Laser Scanning Microscope, Japan). Morphology of micromycetes and trends of its spatial distribution on the rock surface were studied using light microscope (Leica DM 1000) as well as Scanning Electron Microscope (SEM TM 3000, HITACHI, Japan).

\section{Results}

\subsection{Geomorphology of the Studied Area}

In the upper course, in the area directed from the north-east to the south-west, the valley of the Kargy river has a typical trough character: a U-shaped transverse profile (Figure 2), which indicates its glacial past. The glacial processes of erosion and sedimentation are also reflected in the stepped longitudinal profiles of the valley (Figure 2).

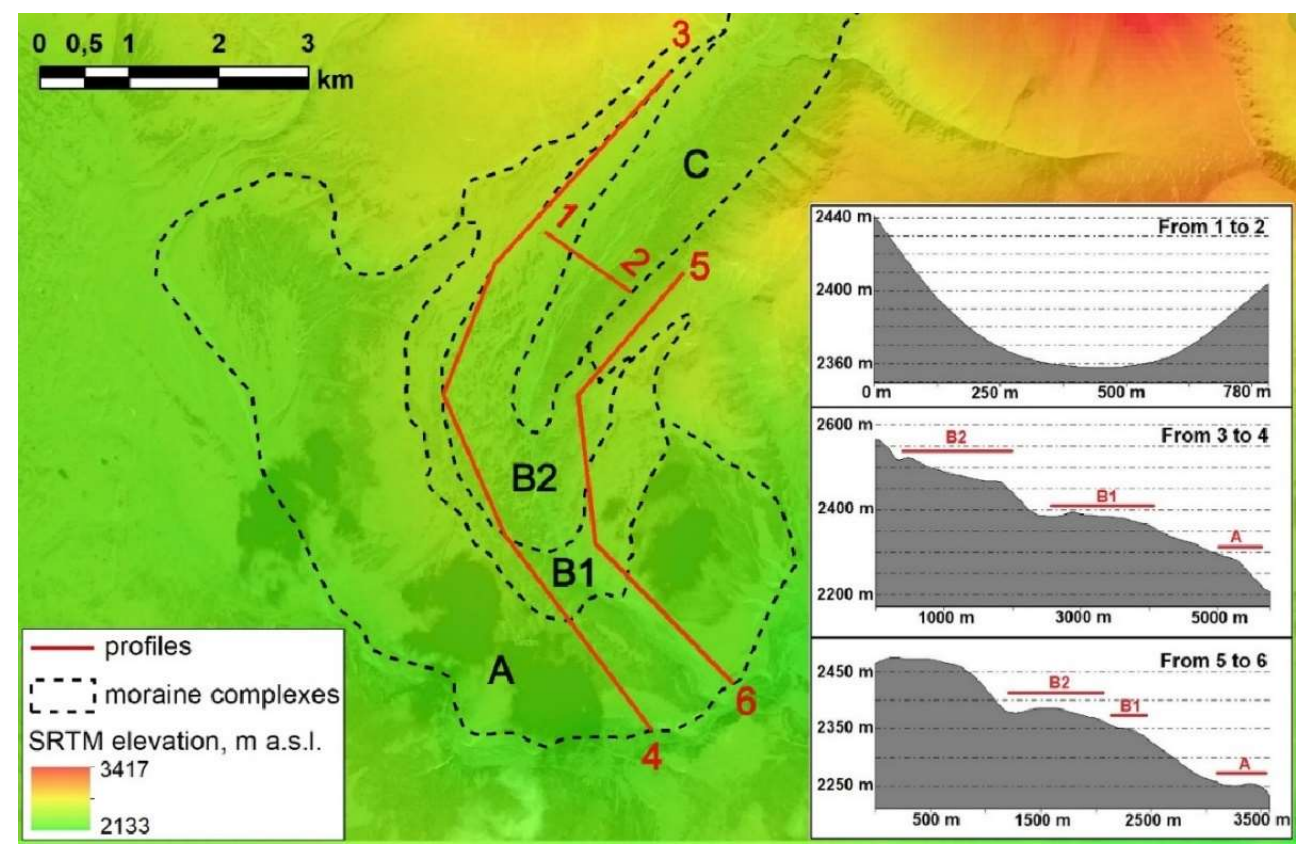

Figure 2. Profiles of the Kargy valley (based on Sentinel-2 image and semitransparent digital elevation model SRTM). Profiles are created in Global mapper. A, B, C-groups of moraines.

In the lower reaches of the Kargy river, moraine deposits are typical in morphology and position for the region and similar to glacial deposits of the Mongun-Taiga mountain range. The lowest are the most ancient moraines (group A) in appearance, is strongly leveled, with rare boulders buried in moraine material. These moraines are located in the altitude interval $2185-2500 \mathrm{~m}$ a.s.l., in the axial part of the valley $2185-2275 \mathrm{~m}$ a.s.l. In plan 
the moraine has a lobed shape (Figure 2). Summarizing data, we concluded that the glacier was coming out of the valley and spreading out.

The younger formations (group B) embedded in the above moraine are typical knoband-kettle moraine formations. These moraines are clearly subdivided into two stages (B1 and B2), along the valley they reach the elevations of 2250 and $2290 \mathrm{~m}$ a.s.1., respectively. The glacier protruded from the narrow part of the valley, turning in its movement from the south-west to south-south-east direction, but was too short to reach its flatter part, forming only a slight expansion.

The next moraine complex (group C) is nested in more ancient moraines of group B. This is a moraine of a valley glacier, the moraine is situated on the steep slopes of the trough and it has been strongly eroded, there is no clearly visible moraine rampart. The lower point of the glacier was located at an altitude of $2325 \mathrm{~m}$ a.s.l. On the north-western side of the trough, the upper limit of the distribution of this moraine is 100 meters below the upper edge of the B2 moraines, which probably reflects the difference in glacier thickness during these epochs. Any younger moraines located up the valley above the group $\mathrm{C}$ moraines were not found (Figure 2). Thus, three groups of moraines of different age were identifies based on detailed investigation of morphological features.

\subsection{The Age of Moraines Based on Relative-dating}

Two of the studied polygons are located on the moraines of the group A: its surface is monotonic in terms of vegetation cover and occurrence of boulders. The largest number of polygons (5) was selected on the territory of complex B1, the length of which is the greatest, 3 polygons are within the complex B2. No horizontal sites with erosion-resistant surfaces could be identified on the territory of complex $C$; therefore, no work on relative dating was carried out here.

\subsection{Petrography and Mineralogy of Moraines}

The moraine samples are represented by fine-grained shale, which is dense, weakly layered, and colored from dark gray to black. The shale belongs to the group of regional metamorphism rocks from green shale facies. Most probably, the primary rock was represented by sandstone. The main rock-forming minerals are quartz (45\%), chlorite (pennine) (25\%), and sericite (7\%). Two generations of quartz were identified: (i) corroded and deformed due to metamorphism within larger $(\sim 0.1 \mathrm{~mm})$ grains and (ii) smaller $(<0.01$ $\mathrm{mm}$ ) grains. Additionally, actinolite, albite, and rare thin streaks of calcite were found. Calcite is not related to green shale facies and belongs to younger generation (Figure 3 ). Iron (hydr)oxides are represented by the separate grains of magnetite and in lesser degree goethite. The presence of thin and light brown films of goethite surrounding the chlorite grains can be attributed to the initial weathering stage of chlorite that is sensitive to weathering and enriched by iron mineral. The process of chlorite weathering has enhanced on the rock surface, leading to the formation of discontinuous reddish rings.
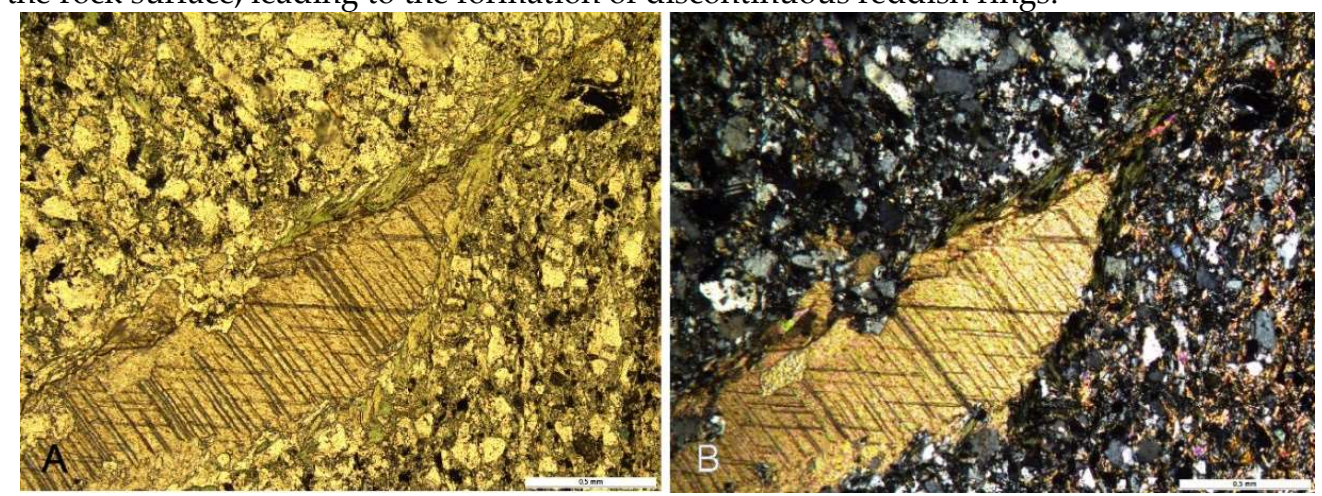

Figure 3. Thin section data of moraine sample within large grain of calcite: a - parallel Nicoli, bcrossed Nicoli. 


\subsection{Specific Surface Area of Moraines and Pore Size Distribution}

Full nitrogen adsorption-desorption isotherms of the samples (Figure 4A) are characterized by expressed capillary condensation hysteresis and refer to the type IV [38], which corresponds to adsorption on mesoporous (diameter $2-100 \mathrm{~nm}$ ) materials. The shape of the hysteresis loop allows to relate it to the type H3 [38], which is observed with non-rigid aggregates of plate-like particles giving rise to slit-shaped pores. The points of joining adsorption and desorption branches of full isotherms are below the values of nitrogen relative pressure $P / P_{0}=0.3$ for all samples, indicating the presence of some amount of micropores (diameter $<2 \mathrm{~nm}$ ) (Figure $4 \mathrm{~B}$ ). All studied samples are characterized by a lognormal size distribution of pores in the range from 1.5 to $15 \mathrm{~nm}$ with maximum $d_{\mathrm{p}}=$ 2.2 (sample from polygon 1), 1.7 (sample from polygon 3, internal part), and $1.9 \mathrm{~nm}$ (sample from polygon 3 , surface part) (Figure $4 \mathrm{~B}$, Table 1 ). The texture characteristics of moraine samples obtained by analysis of full nitrogen adsorption-desorption isotherms using BET and BJH models were summarized in Table 1.
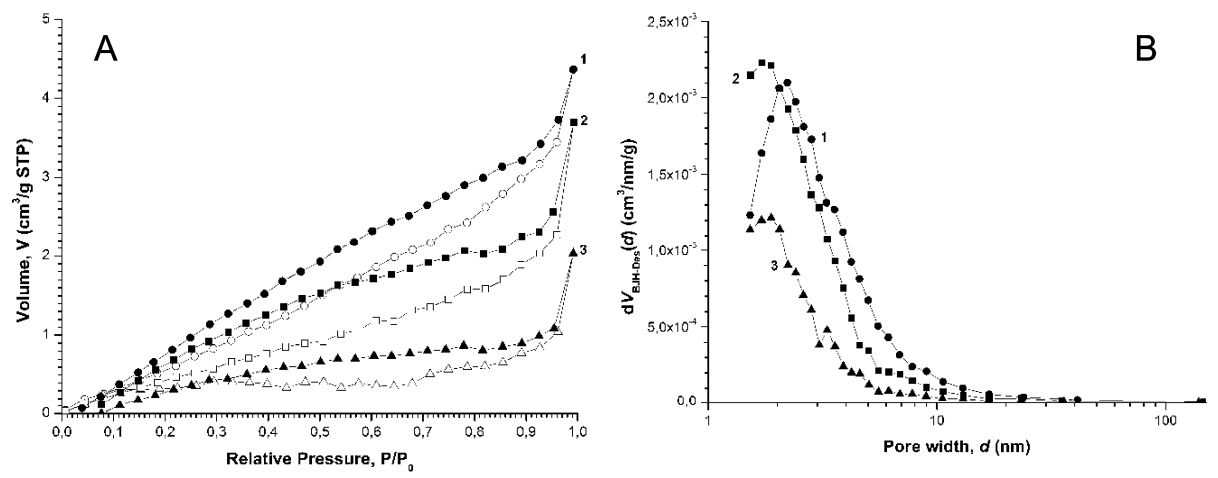

Figure 4. Full nitrogen adsorption-desorption isotherms (A) and their corresponding pore size distributions $d \mathrm{~V}(D)(\mathrm{B})$, obtained from the treatment of full nitrogen adsorption-desorption isotherms within BJH model: (here and in Figure 5) 1 - moraine samples from the polygons N 1 and 3 ( 2 - internal, less weathered part and 3 - surface, more weathered part of the same sample).

Table 1. Parameters of the mesostructure of the moraine samples as obtained from analysis of SANS $(D s=6-n)$ and low-temperature nitrogen absorption data $\left(S_{\mathrm{BET}}, d_{\mathrm{p}}\right.$, and $\left.V_{P / P 0 \rightarrow 0.99}\right)$.

\begin{tabular}{|c|c|c|c|c|c|}
\hline \multirow[b]{2}{*}{ Moraine samples } & & \multicolumn{4}{|c|}{ Structural parameters } \\
\hline & & $D s=6-n$ & $\begin{array}{c}\text { SBET (the } \\
\text { specific } \\
\text { surface } \\
\text { area)/ } \\
\mathrm{m}^{2} / \mathrm{g}\end{array}$ & $\begin{array}{c}d_{\mathrm{p}}(\text { the } \\
\text { average } \\
\text { pore } \\
\text { diameter)/ } \\
\text { nm } \\
\text { BJH (des) }\end{array}$ & $\begin{array}{c}V_{P / P 0 \rightarrow 0.99} \\
\text { (the } \\
\text { specific } \\
\text { pore } \\
\text { volume)/ } \\
\mathrm{cm}^{3} / \mathrm{g}\end{array}$ \\
\hline polygon 1 & & $2.18 \pm 0.02$ & $4.6 \pm 1.2$ & 2.2 & $8.2 \cdot 10^{-3}$ \\
\hline \multirow{2}{*}{ polygon 3} & internal & $2.15 \pm 0.02$ & $2.7 \pm 0.8$ & 1.7 & $6.7 \cdot 10^{-3}$ \\
\hline & surface & $2.14 \pm 0.02$ & $1.3 \pm 0.3$ & 1.9 & $3.9 \cdot 10^{-3}$ \\
\hline
\end{tabular}

\subsection{Mesostructure and Fractal Properties of Moraine Samples}

The experimental curves of the differential neutron cross section $d \Sigma(q) / d \Omega$ versus momentum transfer $q$ for the moraine samples (Figure 5) revealed the same overall shape for all samples and display two characteristic $q$-ranges. In the range of $q<0.7 \mathrm{~nm}^{-1}$, the $d \Sigma(q) / d \Omega$ satisfies the power law $q^{-n}$ (Figure 5). The values of the exponent $n$ were found from the slopes of straight-line segments in the experimental dependences $d \Sigma(q) / d \Omega$ plotted in log-log scale. Their values lie in the range from 3.82 to 3.86 (Table 1). The power 
law exponent in the range $3<n \leq 4$, implies that scattering occurs on the fractal surface with the dimension $2 \leq D_{s}=6-n<3$ [39].

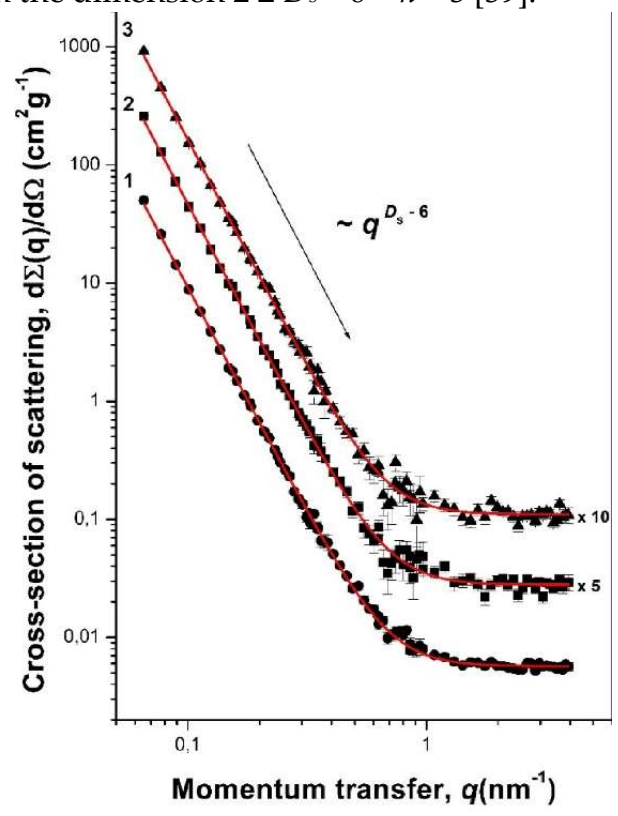

Figure 5. SANS differential cross section $d \Sigma(q) / d \Omega$ versus momentum transfer $q$ for the moraine samples: 1, 2, 3 - moraine samples. Fits of experimental data by equation (1) are shown as solid lines. For the sake of clarity, cross section values for samples from the polygon $\mathrm{N} 3$ were multiplied by 5 and 10 (corresponding factors are given next to the curves).

In the region $q>0.7 \mathrm{~nm}^{-1} \mathrm{~d} \Sigma(q) / \mathrm{d} \Omega$ doesn't depend on $q$ (i.e. becomes a constant). It is caused then by the incoherent scattering by hydrogen atoms included in the composition of the studied samples in the form of a chemical bound or sorbed water. Therefore, the analysis of the observed scattering and the estimation of the lower bound of self-similarity $r$ of the surface fractal are not possible. The absence of a deviation of the $d \Sigma(q) / d \Omega$ curve from the power law (the onset of the Guinier regime) at small values of $q$ means that the upper self-similarity limit $\xi$ of the surface fractal is larger than the maximum size $R_{\max }$ of the inhomogeneities (pores) that can be detected in the experiment with a given resolution: $R_{\max }=3.5 / q_{\min } \approx 60 \mathrm{~nm}$. Thus, the observed scattering patterns are typical for scattering from system possessing a disordered porous (solid phase - pore medium) structure with fractal phase boundaries [40-42] including a natural system represented by rock fragments collected from shallow soils [43] and soil aggregates from mature soils [44].

In view of this circumstance, we used the following expression to analyze the scattering from all samples over the entire q range: $\quad \frac{d \Sigma(q)}{d \Omega}=\frac{A\left(D_{S}\right)}{q^{n}}+I_{\text {inc }} \quad$ (1) where $A\left(D_{\mathrm{s}}\right)$ is power-law prefactor, which depend on the fractal dimensions of the inhomogeneities (pores). The constant $I_{\text {inc }}$ is independent of $q$ and associated with the incoherent scattering of hydrogen atoms.

The expression (1) was convolved with the instrumental resolution function. The experimental curves of $d \Sigma(q) / d \Omega$ versus $q$ were processed by the least mean squares method over the entire measured $q$ range. The results of the analysis of SANS (Figure 5, Table 1) data revealed that all samples are porous systems with a fractal phase boundary. The sample from the polygon $\mathrm{N} 1$ is characterized by a more developed fractal surface $\left(D_{\mathrm{s}}=2.18\right.$ $\pm 0.02)$ than the sample from the polygon N 3 in both unweathered (internal) $\left(D_{s}=2.15 \pm\right.$ $0.02)$ and more weathered surface part $\left(D_{s}=2.14 \pm 0.02\right)$. That is clearly consistent with the data of low-temperature nitrogen adsorption. We supposed that the smaller values (approximately two times) of the specific surface area $S_{\text {вEт }}\left(1.3 \mathrm{~m}^{2} / \mathrm{g}\right)$ and specific volume $V_{P / P 0 \rightarrow 0.99}\left(3.9 \mathrm{~cm}^{3} / \mathrm{g}\right)$ for the surface part of the sample from the polygon $\mathrm{N} 3$ compared to 
its internal part $\left(S_{\mathrm{BET}}=1.3 \mathrm{~m}^{2} / \mathrm{g}\right.$ and $\left.V_{P / P 0 \rightarrow 0.99}=6.7 \mathrm{~cm}^{3} / \mathrm{g}\right)$ are probably due to weathered reddish film, which leads to the closure of part of the pores. The presence of closed pores in the surface of this sample (from polygon 3) is confirmed by the equality, within the experimental error, of the values of the fractal dimension $D s=2.15 \pm 0.02$ (internal, less weathered part) and $2.14 \pm 0.02$ (surface, more weathered part) obtained from the analysis of SANS data.

\subsection{Rock Colonization by Biota}

Crustose lichen dominated on the rock surface was identified as Dimelaena oreina (Ach.) Norman. Its thallus grows tightly with the substrate, penetrating inside to the rock substrate through micro-cracks and deepenings (Figure 6A,B). This lichen inhabits in open, dry and sunny places, mostly in the mountains [45]. The clear pattern of moraine colonization by biota from polygon to polygon was not revealed. That was not a disappointment taking into account two statements: (i) the useful range for lichenometry is 500 years [46], so it cannot be used for the moraines of pre-Holocene age and (ii) in arid conditions the lichen growth rates differ from those of the humid areas of Altai.
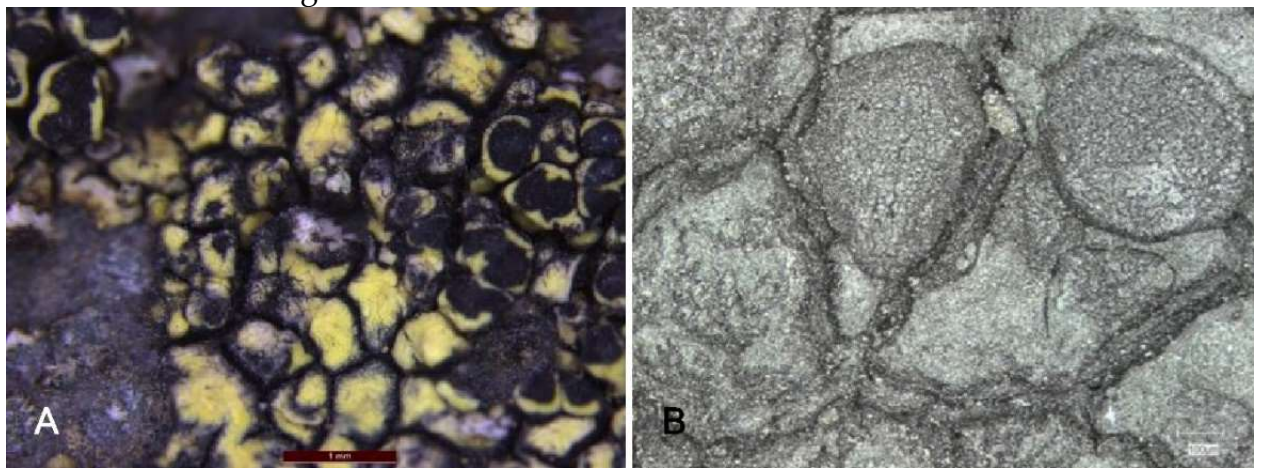

Figure 6. Dominant crustose lichen Dimelaena oreina on the rock surface: A - thallus with fruiting bidies (light Microscope data), B - fruiting bodies (apothecia), embedded into the solid substrate (laser Microscope data).

Micromycetes within specific filamentous structures have formed the mycelium nets composing the continuous layers. They are characterized by irregular distribution mostly on the edge of the rock fragments and micro-cavities; whereas the main part of the rock surface remains uncovered (Figure 7).
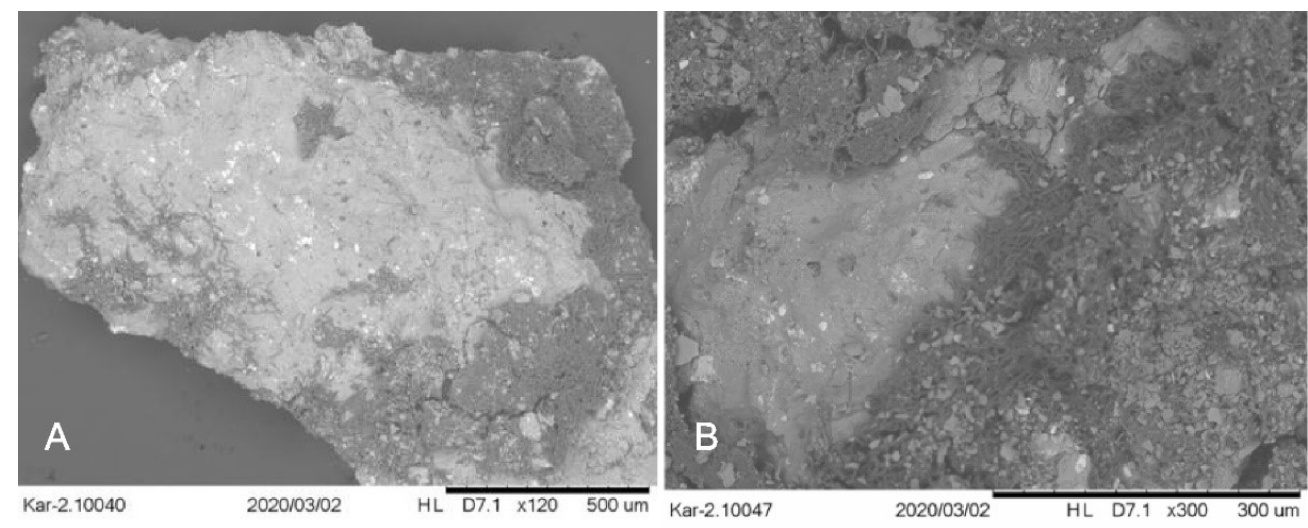

Figure 7. Rock colonization by micromycetes (SEM data): A - formation of biofilm within the predominance of micromycetes on the edge areas of the stone sample; B - boundary of the micromycetes' net and uncovered rock surface. 
In micro-cavities biota can be more protected against external impact and use the organic matter concentrated in the pores, that is a common trend for the north regions [47]. Penetration of micromycetes inside the rock occurred along the pores according to a general trend of solid rock colonization [48]. Based on the studied samples, it was revealed that the growth of biota leads to initial biomass accumulation and rock disintegration along with subsequent autochthonous fine earth accumulations. The latter remain attached due to extracellular polymeric substances released by the biofilms (Figure 8A,B). Thus, the initial stage of fine earth formation was revealed based on data of rock colonization.

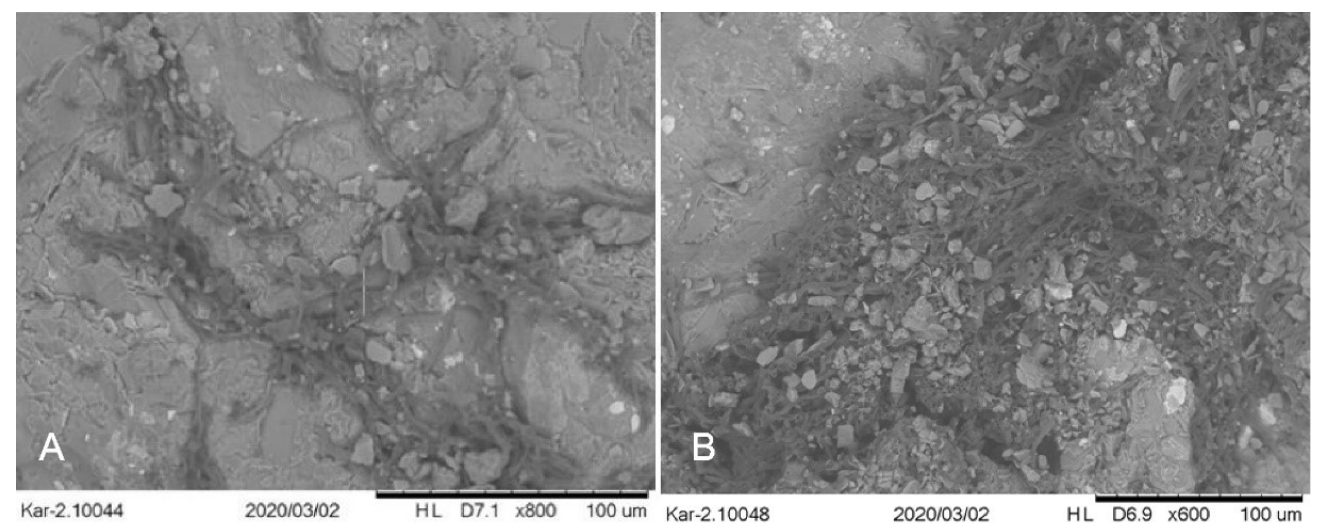

Figure 8. Location of micromycetes on the disintegrated rock surface.

\section{Discussion}

According to the moraines' studies on the territory of the Mongun-Taiga massif, which is adjacent to the Kargy valley, the indicators that most clearly reflect the age of moraines and regularly increase with it are shear-strained boulders percentage $(\mathrm{C})$, their embedment into the finely grained material (B), and the proportion of flat -topped boulders $(F)$. Other factors, like rebound values $(\mathrm{R})$ or lichen coverage (L) rapidly decreased only during the early stage of moraine evolution [28].

However, we do not observe clear trends in changes in any indicators depending on the relative age of the moraines in the Kargy river valley. In our opinion, this is the result of the fact that only ancient, strongly weathered moraines are represented here, while moraines of the late Holocene are absent. This assumption is confirmed by the large differences in the values of each of the studied parameters of the moraines of the Kargy valley from the ones obtained for the Late Holocene moraines of the Mongun-Taiga massif. This is especially true for the parameters B, F and L, which are well within the range of values for moraines MIS 2 and MIS 4. The only exception is the ratio of large and small boulders, which, on the contrary, for the Kargy river basin is close to those of Holocene moraines of the Mongun-Taiga massif. This fact is associated with the peculiarities of the mineralogical composition of rocks in the Kargy valley: the predominance of shale, which leads to a small absolute and relative number of large boulders on the surface of the moraine due to their faster destruction (in the Mongun-Taiga massif, granites predominate, which are more resistant to destruction). Mineralogical differences between these study areas do not allow us to more clearly determine the age of the moraines in the Kargy valley according to the data of relative dating. Nevertheless, on the basis of the data obtained, it is possible to exclude the Holocene age of the Kargy moraines, especially since such factors as B and $\mathrm{L}$ to a small extent depend on the mineralogical composition of boulders.

Based on comparison of the results of relative dating in the Kargy valley and the Mongun-Taiga massif (Table 2), the moraines B1 and B2 correspond to MIS 4 in the Mongun-Taiga massif in terms of the knob-and-kettle relief and in their characteristic position at the point where the trough emerges into the foothills, as well as in their lobed 
shape in plan. Moraine group C position relative to moraines B1 and B2 and being inside the trough corresponds to MIS 2 moraines. It is most difficult to determine the age of moraine $A$, but its strongly smoothed appearance indicates that it is much older than MIS 4 moraines, possibly it belongs to MIS 6 . The estimations of the moraine age are indirectly confirmed by mesostructure data of the studied moraine samples: the sample from the polygon N 1 (presumably MIS 6) is characterized by a more developed fractal surface than the sample from the polygon N 3 (MIS 4-2), which taken into account the similarity of samples mineralogy can be affected by weathering time.

Table 2. Comparison of the results of relative dating in the Kargy valley and the Mongun-Taiga massif.

\begin{tabular}{|c|c|c|c|c|c|c|}
\hline $\begin{array}{c}\text { Moraine group/ } \\
\text { parameters }\end{array}$ & $\mathbf{N} 1 / \mathrm{N} 2$ & $\mathrm{C}, \%$ & B, $\%$ & $\mathbf{R}$ & $\mathrm{F}, \%$ & $\mathrm{~L}, \%$ \\
\hline \multicolumn{7}{|c|}{ moraines from the Kargy valley } \\
\hline B2 & 0.023 & 39 & $63.3 \pm 16.67$ & $46 \pm 6.7$ & 23.8 & 70 \\
\hline B1 & 0.013 & 48.3 & $60.5 \pm 20.59$ & $41 \pm 8.3$ & 36.8 & 59.5 \\
\hline A & 0.055 & 37.5 & $71 \pm 19.38$ & $43.7 \pm 5$ & 21 & 65.5 \\
\hline \multicolumn{7}{|c|}{ moraines from the North-eastern slope of Mongun-Taiga massif* } \\
\hline \multirow[t]{2}{*}{ Holocene } & 0.03 & 3.3 & $49.3 \pm 1.57$ & $51.3 \pm$ & 3.7 & 29.0 \\
\hline & & & & 2.62 & & \\
\hline \multirow[t]{2}{*}{ MIS 2} & 0.33 & 7.0 & $66.3 \pm 1.83$ & $40.4 \pm$ & 32.1 & 79.2 \\
\hline & & & & 1.80 & & \\
\hline \multirow[t]{2}{*}{ MIS 4} & 0.20 & 13.9 & $73.7 \pm 2.50$ & $44.7 \pm$ & 33.2 & 56.8 \\
\hline & & & & 1.63 & & \\
\hline
\end{tabular}

Note: C - shear-strained boulders percentage (\%), B - their embedment into the finely grained material (\%), F-the proportion of flat -topped boulders (\%), R - rebound values, L - lichen coverage; * data based on [28]

Based on the present results, the trend of moraine distribution according to their age can be summarized in the schema (Figure 9). However, it should be noted that the exact age of the moraines can be established only on the basis of absolute dating, which for the moraines of the Kargy river valley is still impossible, both due to (i) the lack of organic material for ${ }^{14} \mathrm{C}$ dating and (ii) the absence of large boulders with sufficient quartz content, which makes ${ }^{10} \mathrm{Be}$ dating impossible. 


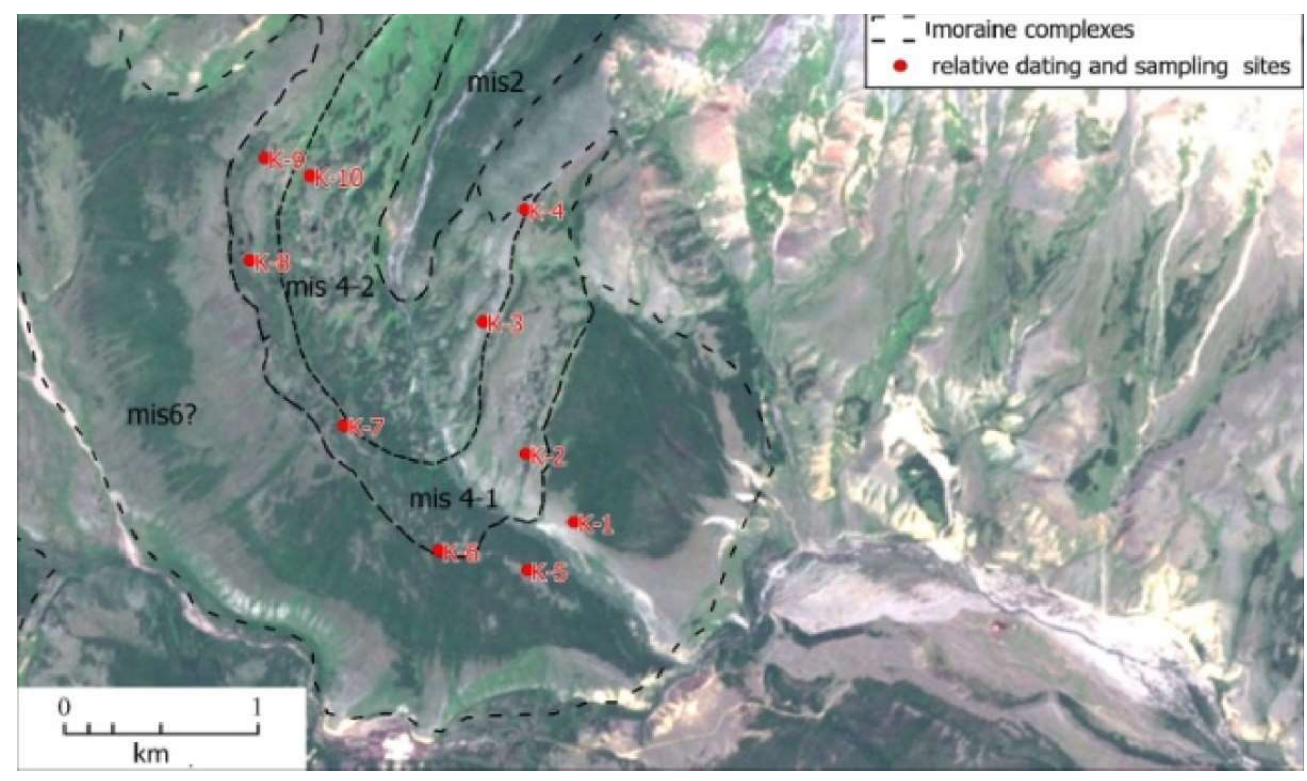

Figure 9. Location of micromycetes on the disintegrated rock surface in the micro-cracks and micro-depressions with fine size rock fragments on mycelial structures (A); and numerous particles of autochthonous rock fragments attached to biofilm (B). SEM data.

Besides, the current state of the studied samples reflects not only the weathering under the present climatic conditions but also their age and weathering in colder/ warmer and dryer/moister periods. Based on the Mongun-Taiga massif studies, the reconstructed range of fluctuations of the average summer temperatures in the Late Pleistocene relative to the present is from -3.8 to $2.5^{\circ} \mathrm{C}$, precipitation fluctuated between 43 to $210 \%$ from present. In the Holocene the corresponding range was from $2.5^{\circ} \mathrm{C}$ and $200 \%$ in the 10580 $6170 \mathrm{cal}$ BP interval to -1.3 and $73 \%$ in the LIA [28].

\section{Conclusions}

The performed relative dating and morphological analysis of the moraines of the Kargy river valley made it possible to distinguish three moraine groups of different ages and to suggest, by analogy with the well-studied Mongun-Taiga massif, that their ages correspond to MIS 2, MIS 4, and MIS 6.

The initial stage of the fine earth formation from the solid rocks affected by biota colonization was observed. It was stated the autochthonous nature of the fine size particles accumulated by the forming biofilms and contributing to the fine earth formation.

The estimations of moraine age (particularly the significant age difference of moraines, confirming their belonging to different glacial epochs) are indirectly confirmed by mesostructure data of the studied moraine samples, characterized by a more developed fractal surface in the older moraine.

Author Contributions: Conceptualization, D.A.G., S.N.L. and K.V.C.; methodology, D.A.G., S.N.L. and K.V.C.; geographic and climatological analysis, A.A.; investigation, D.A.G. (moraine mapping, field relative moraine dating), D.Y.V. (biota), G.P.K. and L.A. (porosity), E.G.P. (mineralogy), E.S.D. (field moraine relative dating, moraine material sampling) ; data curation, D.A.G. and S.N.L; writing-original draft preparation, D.A.G. and S.N.L.; writing - review and editing, D.A.G. and S.N.L; supervision, D.A.G.; project administration, D.A.G. and S.N.L.; funding acquisition, D.A.G. and S.N.L.

Funding: This research was funded by Russian Foundation for Basic Research (RFBR), grant numbers 20-04-00888 and 19-05-00535.

Acknowledgments: RFBR 20-04-00888 and 19-05-00535. The authors thank Institute for Solid State Physics and Optics (Neutron Spectroscopy Department) of Hungarian Academy of Sciences for the 
possibility of carrying out a neutron experiment at the facility "Yellow submarine" (reactor BRR, Budapest Neutron Centre, Hungary). Laser Microscope analyses were carried out in Soil Science Institute, Leibniz University Hannover within DAAD financial support (research stay of $S$. Lessovaia). The study of rock thin sections and SEM analyze were carried out in the research park of St.-Petersburg State University - "X-ray Diffraction Centre" and "Centre for microscopy and microanalysis", correspondently. The authors also thank M. Zelenskaya (SEM study) and E. Stepanchikova (identification of lichen) for help).

Conflicts of Interest: The authors declare no conflict of interest.

\section{References}

1. Wagner G.A. Age Determination of Young Rocks and Artifacts. Berlin Heidelberg, Springer: 466pp. Berlin Heidelberg, 1998. $466 \mathrm{p}$.

2. Gribenski N. et al. Complex patterns of glacier advances during the late glacial in the Chagan Uzun Valley, Russian Altai // Quaternary Science Reviews. Elsevier Ltd, 2016. Vol. 149. P. 288-305.

3. Herget J. et al. Comment on Gribenski, N. et al., 2016. Complex patterns of glacier advances during the late glacial in the Chagan Uzun Valley, Russian Altai. Quaternary Science Reviews 149, 288-305 // Quaternary Science Reviews. 2017. Vol. 168. P. 216219.

4. Gribenski N. et al. Reply to comment received from J. Herget et al. regarding “Complex patterns of glacier advances during the late glacial in the Chagan Uzun Valley, Russian Altai" by Gribenski et al. (2016), Quaternary Science Reviews 149, 288-305 // Quaternary Science Reviews. 2017. Vol. 168.

5. Agatova A.R. et al. THE POSSIBILITY OF TIME CORRELATION OF GORNY ALTAI GLACIATIONS TO SPECMAP TIME SCALE AND SOUTH SIBERIA GLACIATIONS // VI All-Russian meeting on the study of the Quaternary period. 2009. P. 2730.

6. Flint R.F., Fidalgo F. Glacial geology of the east flank of the Argentine Andes between latitude $39^{\circ} 10^{\prime} \mathrm{S}$. and latitude $41^{\circ} 20^{\prime} \mathrm{S} / /$ Geol. Soc. America Bull. 1964. Vol. 75. P. 335-352.

7. Sharp R.P., Birman J.H. Additions to the classical sequence of Pleistocene glaciations // Geol. Soc. America Bull. 1963. Vol. 74. P. 1079-1086.

8. Birman J.H. Glacial geology across the crest of the Sierra Nevada // Geol. Soc. America Spec. Paper. 1964. Vol. 75. P. 80.

9. Flint R.F., Fidalgo F. Glacial Drift in the Eastern Argentine Andes between Latitude $41^{\circ} 10^{\prime}$ S. and Latitude $43^{\circ} 10^{\prime} \mathrm{S} / /$ Geol. Soc. America Bull. 1969. Vol. 80. P. 1043-1052.

10. Sharp R.P. Semiquantitative Differentiation of Glacial Moraines near Convict Lake, Sierra Nevada, California // The Journal of Geology. The University of Chicago Press, 1969. Vol. 77, № 1. P. 68-91.

11. Porter S.C. Quaternary Glacial Record in Swat Kohistan, West Pakistan // Geological Society of America Bulletin. 1970. Vol. 81, № 5. P. 1421-1446.

12. Devyatkin E. V., Murzaeva V.J. Opyt raschlenenija moren po kompleksu litologo-geomorfologicheskih priznakov // Izvestija Vsesojuznogo Geograficheskogo Obshhestva. 1979. Vol. 111, № 4. P. 342-348.

13. Crook R., Gillespie A.R. Weathering rates in granitic boulders measured by p-wave speeds. // Rates of Chemical Weathering of Rocks and Minerals / ed. Colman S.M., Dethier D.P. Orlando, FL.: Academic Press, 1986. P. 395-117.

14. Bursik M. Relative dating of moraines based on landform degradation, Lee Vining Canyon, California // Quaternary Research. 1991. Vol. 35, № 3, Part 1. P. 451-455.

15. Schmidt E.A. Non-destructive concrete tester. // Concrete. 1951. Vol. 59. P. 34-35.

16. Matthews J.A., Shakesby R.A. The status of the "Little Ice Age" in southern Norway: relative age dating of Neoglacial moraines with Schmidt hammer and lichenometry // Boreas. 1984. Vol. 13, № 3. P. 333-346.

17. Winkler S., Shakesby R.A. Anwendung von Lichenometrie und Schmidt-Hammer zur relativen Altersdatierung präfrührezenter Moränen am Beispiel der Vorfelder von Guslar-, Mitterkar-, Rofenkar- und Vernagtferner (Ötztaler Alpen/Österreich) // Petermanns Geographische Mitteilungen. 1995. № 139. P. 283-304.

18. Rune Aa A., Sjåstad J.A. Schmidt hammer age evaluation of the moraine sequence in front of Bøyabreen, western Norway // Norsk Geologisk Tidsskrift. Taylor \& Francis, 2000. Vol. 80, № 1. P. $27-32$.

19. Sharma P.K., Khandelwal M., Singh T.N. A correlation between Schmidt hammer rebound numbers with impact strength index , slake durability index and P-wave velocity // nternational Journal of Earth Sciences. 2011. Vol. 100, № 1. P. $189-195$.

20. Wolman M.G. A method of sampling coarse river-bed material. // Transactions of the American Geophysical Union. 1954. Vol. 35, № 6. P. 951-956.

21. Sampson K.M., Smith L.C. Relative Ages of Pleistocene Moraines Discerned from Pebble Counts: Eastern Sierra Nevada, California // Physical Geography. Taylor \& Francis, 2006. Vol. 27, № 3. P. 223-235.

22. Chinn T.J.H. Use of Rock Weathering-Rind Thickness for Holocene Absolute Age-Dating in New Zealand // Arctic and Alpine Research. Taylor \& Francis, 1981. Vol. 13, № 1. P. 33-45.

23. Gellatly A.F. The Use of Rock Weathering-Rind Thickness to Redate Moraines in Mount Cook National Park, New Zealand // Arctic and Alpine Research. Taylor \& Francis, 1984. Vol. 16, № 2. P. 225-232. 
24. Ricker K.E., Chinn T.J., McSaveney M.J. A late Quaternary moraine sequence dated by rock weathering rinds, Craigieburn Range, New Zealand // Canadian Journal of Earth Sciences. 1993. Vol. 30, № 9. P. 1861-1869.

25. Oguchi C.T. Formation of weathering rinds on andesite // Earth Surface Processes and Landforms. John Wiley \& Sons, Ltd, 2001. Vol. 26, № 8. P. 847-858.

26. Haeberli W. et al. Methods for absolute and relative age dating of rock-glacier surfaces in alpine permafrost. 2002.

27. Pearson A., Ariunzaya K., Batbol D. Relative age dating of moraines and determination of maximum ice cover in the Egiin Davaa area, Hangay Mountains, Mongolia // Proceedings of the 20th Annual Keck Symposium. 2007. P. 44-48.

28. Ganyushkin D. et al. Palaeoclimate, glacier and treeline reconstruction based on geomorphic evidences in the Mongun-Taiga massif (south-eastern Russian Altai) during the Late Pleistocene and Holocene // Quaternary International. Pergamon, 2018. Vol. 470. P. 26-37.

29. Chistyakov K.V. et al. Gornyj massiv Mongun-Tajga. Saint-Petersburg: V.V.M., 2012. 310 p.

30. Ganyushkin D.A. et al. Present glaciers and their dynamics in the arid parts of the altai mountains // Geosciences (Switzerland). 2017. Vol. 7, № 4 .

31. Ganyushkin D.A. et al. Interpretation of Glaciogenic Complexes From Satellite Images of the Mongun-Taiga Mountain Range // Geography and Natural Resources. 2018. Vol. 39, № 1.

32. Goudie A.S. The Schmidt Hammer in geomorphologlical research // Progress in Physical Geography. 2006. Vol. 30, № 6. P. 703718.

33. Shakesby R.A., Matthews J.A., Owen G. The Schmidt hammer as a relative-age dating tool and its potential for calibrated-age dating in Holocene glaciated environments. , . // Quaternary Science Reviews. 2006. № 25. P. 2846-2867.

34. Böhlert R. et al. Application of a combination of dating techniques to reconstruct the Lateglacial and early Holocene landscape history of the Albula region (eastern Switzerland) // Geomorphology. 2011.

35. Anovitz L.M., Cole D.R. Characterization and analysis of porosity and pore structures // Rev Mineral Geochem. 2015. Vol. 80. P. 61-164.

36. Wignall G.D., Bates F.S. Absolute calibration of small-angle neutron scattering data // Journal of Applied Crystallography. Wiley-Blackwell, 1987. Vol. 20, № 1. P. 28-40.

37. Keiderling U. The new "BerSANS-PC" software for reduction and treatment of small angle neutron scattering data // Applied Physics A: Materials Science and Processing. 2002. Vol. 74. P. 1455-1457.

38. IUPAC. The International Union of Pure and Applied Chemistry classification [Electronic resource]. URL: https://iupac.org/.

39. Teixeira J. Experimental Methods for Studying Fractal Aggregates // On Growth and Form. 1986. P. 145-162.

40. Kopitsa G.P. et al. Mesostructure of xerogels of hydrated zirconium dioxide // JETP Letters. 2007. Vol. 85, № 2. P. $122-126$.

41. Ivanov V.K. et al. Ultrasound-induced changes in mesostructure of amorphous iron (III) hydroxide xerogels: A small-angle neutron scattering study // Physical Review B - Condensed Matter and Materials Physics. 2010. Vol. 81, № 17.

42. Simonenko E.P. et al. A sol-gel synthesis and gas-sensing properties of finely dispersed ZrTiO 4 // Materials Chemistry and Physics. Elsevier Ltd, 2019. Vol. 225. P. 347-357.

43. Lessovaia S.N. et al. Modeling biogenic weathering of rocks from soils of cold environments // Lecture Notes in Earth System Sciences. Springer International Publishing, 2020. P. 501-515.

44. Fedotov G.N. et al. Fractal colloidal structures in soils of various zonalities // Doklady Chemistry. 2005. Vol. 405, № 1-3. P. 240242.

45. Calatayud V., Rico V.J. Chemotypes of Dimelaena oreina (Ascomycotina, Physciaceae) in the Iberian Peninsula // Bryologist. American Bryological and Lichenological Society Inc., 1999. Vol. 102, № 1. P. 39-44.

46. Innes J.L. Lichenometry // Progress in Physical Geography: Earth and Environment. SAGE Publications Ltd, 1985. Vol. 9, № 2. P. 187-254.

47. Yu. Vlasov D. et al. Changes of Granite Rapakivi under the Biofouling Influence // Geochemistry [Working Title]. IntechOpen, 2020.

48. Gorbushina A.A. Life on the rocks // Environmental Microbiology. 2007. Vol. 9, № 7. P. 1613-1631.Author 1, A.B. (University, City, State, Country); Author 2, C. (Institute, City, State, Country). Personal communication, 2012. 